\section{Biological foundation for periodontitis as a potential risk factor for atherosclerosis}

\author{
Chun $Y-H P$, Chun $K-R J$, Olguin D'A, Wang H-L. Biological foundation for \\ periodontitis as a potential risk factor for atherosclerosis. J Periodont Res 2005; 40: \\ 87-95. (C) Blackwell Munksgaard 2004
}

Objectives: Links between periodontal diseases and systemic diseases have been well documented by epidemiological studies. Recently, research has shifted to elucidating the biologic mechanism for a causal relationship. One focus of interest is atherosclerosis, the underlying event of cardiovascular diseases due to its serious health impact. However, it is still not clear whether periodontopathic pathogens are truly etiologic agents or ubiquitous bystanders. This article reviews the current understanding about the molecular biological interactions between periodontal disease and atherosclerosis and the biological plausibility of periodontitis as a potential risk factor for cardiovascular disease.

Materials and methods: The current literature regarding periodontal diseases and atherosclerosis and coronary vascular disease was searched using the Medline and PubMed databases.

Results: In vitro experiments and animal models are appropriate tools to investigate the biological interactions between periodontal disease and atherosclerosis at the cell molecular level. The concepts linking both pathologies refer to inflammatory response, immune responses, and hemostasis. In particular,

Porphyromonas gingivalis appears to have unique, versatile pathogenic properties. Whether or not these findings from isolated cells or animal models are applicable in humans with genetic and environmental variations is yet to be determined. Likewise, the benefit from periodontal therapy on the development of atherosclerosis is unclear. Approaches targeting inflammatory and immune responses of periodontitis and atherosclerosis simultaneously are very intriguing.

Conclusion: An emerging concept suggests that a pathogenic burden from different sources might overcome an individual threshold culminating in clinical sequela. $P$. gingivalis contributes directly and indirectly to atherosclerosis.

\author{
Yong-Hee P. Chun*, Kyoung-Ryul \\ J. Chun†, De'Avlin Olguin*, \\ Hom-Lay Wang* \\ *Department of Periodontics/Prevention/ \\ Geriatrics, School of Dentistry, University of \\ Michigan, Ann Arbor, Michigan, USA and $†$ AK \\ St. Georg, Medical Clinic II, Department of \\ Cardiology, Hamburg, Germany
}

Dr Hom-Lay Wang, DDS, MSD, Professor and Director of Graduate Periodontics, University of Michigan, School of Dentistry, $1011 \mathrm{~N}$. University Ave., Ann Arbor, MI 48109-1078, USA

Tel: +1 (734) 7633383

Fax: + 1 (734) 7635503

e-mail: homlay@umich.edu

Key words: atherosclerosis; bacteremia; cardiovascular disease; periodontal disease; Porphyromonas gingivalis

Accepted for publication July 20, 2004
Originating in the 1960 s with the landmark Framingham Heart Study, a list of classical risk factors (hyperlipidemia, hypertension, smoking, diabetes mellitus, physical inactivity, obesity, endocrine dysfunction, and abnormalities of hemostasis and thrombosis) for atherosclerosis have been identified (Table 1) (1-3). However, they were not sufficient to account for the etiology of this multifactorial pathological process. Therefore, several novel risk factors have been identified, including micro- bial pathogens, non-specific markers for low-grade inflammation (4), fibrinogen, C-reactive protein (CRP), leukocyte count and antibodies to heat-shock proteins (5-14).

Possible focal origin for systemic spread are the gastrointestinal system, 
Table 1. Risk factors implicated in atherogenesis and periodontal disease

\begin{tabular}{ll}
\hline Not modifiable & Modifiable \\
\hline Gender & Lack of exercise \\
Age & Stress \\
Race & Alcohol consumption \\
Family history & Diet \\
Hypertension & Smoking \\
Diabetes mellitus & Infections \\
Body mass index & C-reactive protein \\
Homocysteine & \\
Lipoprotein a & \\
White blood cells & \\
Fibrinogen & \\
Total cholesterol & \\
Low density lipoprotein \\
\hline
\end{tabular}

Bold type, mutual risk factor of atherosclerosis and periodontitis; regular type, atherosclerosis risk factor.

bronchi, pharynx and periodontium that harbor various putative etiologic pathogens, namely Helicobacter species, Chlamydia species, cytomegalovirus and Porphyromonas gingivalis $(15,16)$. All putative pathogens for atherosclerosis are associated with chronic infections. Helicobacter pylori, Chlamydia pneumoniae, cytomegalovirus, and $P$. gingivalis continually sense and adapt to their environment by expressing factors associated with virulence (17). Although the contribution to atherogenesis of all putative pathogens appears to be biologically plausible, inconsistencies in statistical association [e.g. H. pylori (18-21)], detection in atheromatous plaques of autopsy material [H. pylori (22), cytomegalovirus (23)] query the validity of infection as a risk factor. The penetrance of $50 \%$ of the adults in the US with atherosclerosis and seropositivity for H.pylori, C. pneumoniae, and cytomegalovirus might represent their role as coincidental bystanders.

In this context, it is legitimate to raise the question, whether and which role $P$. gingivalis possibly could play. Extensive epidemiological studies since 1989 have analyzed data related to a statistical association of periodontal disease (24). Variations in study designs, sample number, end points for cardiovascular disease and periodontal disease, assessment of periodontium, accumulation of systemic factors and adjustment for confounding factors might explain the conflicting range of outcome. Even among prospective cohort studies the degree of association fluctuates from strong, e.g. odds ratio 2.68 (25) to negligible or no association, e.g. hazard ratio 0.79 (26) Gathering nine cohort studies in a meta-analysis, the overall relative risk settled at 1.19 (27). Interestingly, the regression analysis uncovered an overestimation of $12.9 \%$ of the results caused by residual confounding after adjustment for risk factors. This illustrates the complexity of multifactorial events.

\section{Systemic effects of $\boldsymbol{P}$. gingivalis}

In order to consider periodontal disease as a risk factor for atherosclerosis, the presence of pathogens associated with periodontal disease should be localized in serum or atheromatous plaques. In addition, these pathogens should induce the release of proinflammatory cytokines. Lastly, animal models demonstrating atherosclerosis induced by periodontal pathogen should be available.

Among periodontal pathogens, $P$. gingivalis has been recognized as a key pathogen and risk factor for periodontal disease (28-30). Its degree of pathogenicity has been attributed to various virulence factors. Most significant is its ability to invade epithelial cells $(31,32)$, connective tissue (33) and endothelial cells (34). The invasion of $P$. gingivalis is mediated through up-regulation of adhesion molecules, such as intercellular adhesion molecule 1 (ICAM-1), vascular cell adhesion molecule 1 (VCAM-1), P- and E-selectins, only in the presence of fimbriae. The activation of adhesion molecules is also required to bind leukocytes to endothelium, which initiates transmigration and atherogenesis (35) (Fig. 1). A systemic host response is elicited shown as elevated serum and saliva antibody to $P$. gingivalis in $P$. gingivalis infected periodontitis patients $(36,37)$

$P$. gingivalis lipopolysaccharides trigger inflammatory pathways through cytokine production (tumor necrosis factor, interleukin-1, prosta- glandin $\mathrm{E}_{2}$ ). The concept of 'focus of infection' (38) and 'oral sepsis' (39) holds that transient bacteremias occur from dental infection, surgical dental procedures $(40,41)$, periodontal probing (42), and mastication (43).

Possible etiologic roles of periodontal infections in atherogenesis include bacteria and their byproducts damaging the vessel wall and subsequent metastatic infection. These events indirectly promote atheroma formation through the inflammatory response induced by periodontal or metastatic infection (23).

Biopsy studies on carotid endarterectomy specimens have demonstrated the presence of periodontal pathogens in atheromas (44). Forty-four per cent of the atheromas were found to be positive for at least one periodontal pathogen. $P$. gingivalis was identified in $26 \%$ of the samples by polymerase chain reaction.

Access of pathogens to systemic circulation has been linked to atherosclerosis and thrombus formation (45). Endothelial cell damage has been shown to be promoted by the ability of $P$. gingivalis to adhere, invade, and proliferate in coronary endothelial cells $(34,46,47)$. This phenomenon is believed to interfere with the physiologic dilatory function of the vessels through the pathogen's damage of the endothelial and smooth muscle cells (48). When the former in vitro findings were translated to a cohort study, this association was further strengthened, as it was found that periodontitis patients had significantly compromised flow-mediated dilation (49).

Similar evidence has been provided in animal models, specifically the use of apolipoprotein E-deficient mice (apoE) (50). Although mice are in general resistant to atherosclerosis, inactivation of the apoE gene leads to alterations in the lipid metabolism (51). Therefore, apoE $(-/-)$ mice are known to develop atherosclerosis spontaneously, whereas heterozygous apoE $(+/-)$ mice are more prone to atherosclerosis compared to apoE $(+/+)$ mice $(52,53)$. In conjunction with $P$. gingivalis, more pronounced effects on alveolar bone loss, foam 


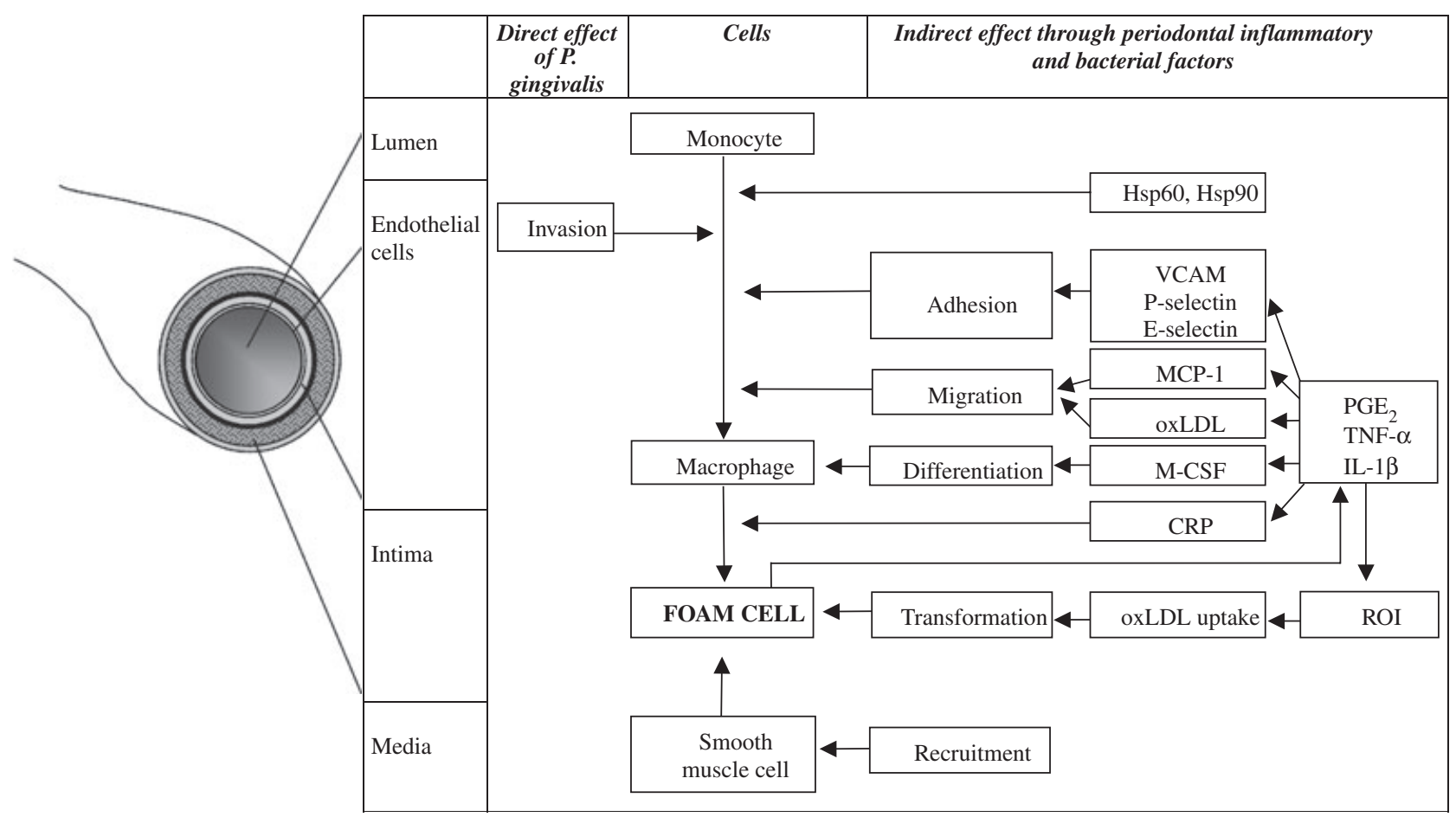

Fig. 1. Process of atherogenesis and role of direct and indirect periodontal factors. Periodontal pathogens may directly and indirectly affect blood cells and blood vessels resulting in foam cell formation, the hallmark of atherosclerosis. CRP, C-reactive protein; Hsp, heat shock protein; IL-1 $\beta$, interleukin-1 $\beta$; MCP-1, monocyte attractant protein-1; M-CSF, macrophage colony-stimulating factor; oxLDL, oxidized lowdensity lipoprotein; $\mathrm{PGE}_{2}$, prostaglandin $\mathrm{E}_{2}$; ROI, rate of infection; TNF- $\alpha$, tumor necrosis factor- $\alpha$; VCAM, vascular cell adhesion molecule.

cell formation and atherosclerotic lesions were consistently found in inoculated apoE null mice. P. gingivalis was administrated by intravenous injection (54) or by oral inoculation (55). Several lines of evidence confirm a role of $P$. gingivalis on atherogenesis.

\section{P. gingivalis' contribution to initiating events of atherosclerosis}

Atherosclerosis is believed to be mediated by inflammatory events (56). Atheromas are a result of the progressive accumulation of cholesterol and its esters in macrophages of the intima, termed foam cells (56-58). Cytokines have been identified in the atherosclerotic plaque to regulate recruitment of monocytes, endothelial adhesion molecules, oxidized low-density lipoproteins (LDL) uptake, smooth muscle cell proliferation, and hemostatic factors $(45,59,60)$. The release of cytokine from macrophages and other cells is thought to be triggered by bacterial components leading to systemic activation of phagocytic cells, a mechanism well know to be associated with $P$. gingivalis lipopolysaccharide $(57,61)$. Prostaglandin $E_{2}$, interleukin$1 \beta$, and tumor necrosis factor- $\alpha$ derived from periodontitis reach high and potent systemic levels (62). This increased release of proinflammatory cytokines actively recruits more inflammatory cells, which furthermore may result in higher counts of foam cells. For example, endothelial cells stimulated by bacterial products release monocyte attractant protein-1 (MCP-1). MCP-1 mediates transendothelial migration of monocytes via chemotaxis. Mice with deficient levels of MCP-1 have been shown to have less atherosclerotic plaque development (63). However, it has been shown that $P$. gingivalis induces $\mathrm{MCP}-1$ in endothelial cells in vitro (64). This implies that $P$. gingivalis may contribute to the development of atherosclerosis. However, the molecular mechanism of this finding requires in depth elucidation.

\section{Development of atherosclerotic lesion requires foam cell formation}

Cholesterol-laden macrophages, or as foam cells, are indispensable in the progression of atherogenesis and plaque instability. Components of $P$. gingivalis increase the uptake of LDL in murine macrophages (65). This has also been shown to induce foam cell formation in human umbilical vein endothelial cells (66). Cholesterol accumulations in macrophages are the hallmark of atherosclerotic lesions (Fig. 1). The uptake of LDL by macrophages requires oxidation to oxLDL. The oxidation is driven by the generation of reactive oxygen intermediates in macrophages in the vessel wall in response to bacteria. Macrophages transform to foam cells and stimulate the production of proinflammatory cytokines, leading to endothelial dysfunction.

Periodontitis is known as a potent source for reactive oxygen intermediates (67). A strong correlation between 
periodontitis and lipid deposition in the aorta was shown in a rabbit model (68). Periodontitis was induced by topical application of $P$. gingivalis and the correlation remained strong, although two out of five rabbits of the $P$. gingivalis-treated group failed to develop periodontitis and lipid depositions. Future studies are needed to confirm this interesting finding.

\section{Immunologic response and lesion progression}

Smooth muscle cells proliferate during progression to a fibrous cap into the subendothelial space where they take up oxLDL and form extracellular matrix (58). The T-cell response further contributes to foam cell formation and smooth muscle formation through cytokine production.

Another immunologic-related mechanism involves the homology of bacterial heat shock proteins (Hsp) with host proteins, which may lead to crossreactivity. T-cells and antibodies may recognize epitopes shared by both host and infectious organism Hsps, thereby initiating and/or perpetuating atherosclerotic plaque formation $(13,14)$.

Among several other human tissues, Hsp is produced in the endothelium lining the vessel wall. It responds to certain stressors, such as high blood pressure and exposure to lipopolysaccharide, by producing Hsp60 (69), antibodies and facilitating cross-reactions. This immunological cross-reaction might result in cell damage and proliferation of smooth muscle cells (70). P. gingivalis has an Hsp60 (71) and an Hsp90 homologue (5), which were found to cross-react with the corresponding human Hsp. It has been illustrated that patients with higher levels of anti-Hsp antibodies had less destruction of periodontal tissues (72). Conversely, the inability to produce anti-Hsp antibodies might contribute to tissue destruction induced by pathogens.

Recent animal models using immunization with human Hsp60 have confirmed the role of Hsps for atherogenesis $(73,74)$. Besides the significant development of fatty streaks, periodontal inflammation was present in the test group (74). A T-cell response specific to Hsp60 of $P$. gingivalis was found in the serum and atheromas of patients with periodontal disease and atherosclerosis (75-77). Interestingly, this T-cell response appears to be characteristic for $P$. gingivalis; it failed to demonstrate association with other periodontal pathogens, e.g. Actinobacillus actinomycetemcomitans, Capnocytophaga sputigena, and Eikenella corrodens (76). Evidence suggests that $P$. gingivalis Hsps circulate in the blood and eventually cross-react with endothelium and atheroma. Immunebased therapy might be a promising approach for atherosclerosis and periodontal diseases, in particular refractory cases. Nevertheless, the molecular interactions need to be further elucidated first.

Elevated serum levels of CRP, an acute-phase reactant to inflammation, is induced by non-specific, local and systemic tissue damage, infection and inflammation. Evidence from wellconducted prospective studies identified CRP as a strong marker of future vascular events (78-81). Only highsensitivity CRP assays are valid to predict future cardiovascular events, with a serum concentration of $<1,1-3$ and $>3 \mu \mathrm{g} / \mathrm{ml}$ considered as low, intermediate and high risk, respectively, for a cardiovascular event. CRP is linked to atherogenesis through production of cytokines such as interleukin-1, interleukin-6, tumor necrosis factor- $\alpha$, and interferon- $\gamma$. Binding of LDL and formation of foam cells is mediated by CRP (82-85). The terminal complement complex (C5b-9) is activated (86-88). In addition to systemic effects, CRP might be amplified by local CRP accumulation in atheromas (89). Cross-sectional data revealed a positive correlation of CRP levels and markers of endothelial dysfunction $(90,91)$. However, the carotid intimal medial thickness detected by ultrasound failed to demonstrate a direct effect $(84,92)$. In contrast to studies before 2000, evidence from a large scale meta-analysis including 22 prospective studies showed a decrease in odds ratio of CRP as a marker for coronary heart disease and resulted in an overall odds ratio of 1.58 (93).
As periodontitis has a high incidence in an adult population and because of the chronic nature of the disease, it seems likely that it also affects the body systemically. The systemic effect of periodontitis has been shown in a positive association between increased CRP levels and periodontitis by several groups in cross-sectional and prospective studies (94-102). CRP appears to be consistently elevated in a doseresponse fashion to the pathogenic burden of periodontal bacteria $(96,98$, 103, 104). As part of the Erie County study (28), serum samples and carotid endarterectomy samples were taken from 16 subjects. These subjects had periodontal disease, defined as a mean attachment loss of $\geq 4 \mathrm{~mm}$, and a positive history of cardiovascular disease. In a follow-up study, the serum was analyzed for CRP by enzymelinked immunosorbent assay and immunohistochemistry (100). In the presence of both diseases, CRP was significantly elevated in $75 \%$ of the subjects, with a mean CRP level of $8.58 \mu \mathrm{g} / \mathrm{ml}$, compared to $39 \%$ in the absence of both diseases and a CRP level of $1.68 \mu \mathrm{g} / \mathrm{ml}$. Non-surgical intervention consisting of scaling and root planing and antibiotics resulted in reduced CRP levels (105). Interestingly, baseline CRP was elevated only in a fraction of the patients who preferentially demonstrated the decrease of CRP. This suggests that the association of CRP and periodontal disease is more dimensional. In addition, the sensitivity of the CRP testing method and its specificity for periodontitis vs. other infections have to be taken into consideration.

\section{Plaque stability and thrombosis}

During the progression of a fibrous plaque, atheroma cells may undergo apoptosis, necrosis, and mineralization culminating in release of lipids and further narrowing of the vessel lumen. Plaque rupture subsequently leads to thrombosis of the vessel, the underlying biological event of ischemia and myocardial infarction $(56,106,107)$. The coagulation cascade is simultaneously initiated. 
Destabilization of pre-existing atherosclerotic plaques occurs in the presence of vascular stenosis. Oral bacteria stimulate platelet aggregation and thrombus-like formation in vitro (108). When Streptococcus sanguis was infused in rabbits, it was shown that myocardial, infarction-like symptoms were developed in a dose-dependent manner (109). Among several periodontal pathogens, $P$. gingivalis was the only one to trigger platelet aggregation (110). It was demonstrated that $P$. gingivalis vesicles and fimbriae are critical for aggregation and adherence, respectively. Furthermore, P. gingivalis-induced platelet aggregation might precede thromboembolic events.

Matrix metalloproteinases derived from macrophages are thought to weaken the fibrous cap of the atheroma, thus promoting plaque rupture. Periodontal pathogens are known to induce matrix metalloproteinases and might contribute to plaque rupture (111). In vitro, P. gingivalis has demonstrated the ability to degrade human atheroma samples.

\section{Clinical signs of atherosclerosis in the presence of periodontal disease}

Imaging and laboratory diagnostics are suitable tools to detect subclinical evidence for atheromatous plaques and occurrence/progression. The stateof-the-art imaging diagnostics of new atheromatous plaques and occurrence/ progression of vessel stenosis include high-resolution duplex scanning (ultrasound) with a $10-\mathrm{MHz}$ imaging probe and 5-MHz Doppler probe. The high resolution allows valid evaluation of the intima-media thickness and changes of the carotid vessel wall over time $(112,113)$.

In accordance with chronic, systemic infections, a dose-dependent effect was found in severe periodontal disease related to the intima-media wall thickness of the carotid artery (114). This large-scale cross-sectional study was part of the Atherosclerosis Risk in Communities (ARIC) study. The disease definitions included an increase in vessel wall thickness by ultrasound of $\geq 1 \mathrm{~mm}$, and attachment loss $\geq 3 \mathrm{~mm}$ in $\geq 30 \%$ of sites was considered severe periodontal disease. The adjusted odds ratio was 1.3 . The odds ratio was 1.6 for positive B-mode ultrasound findings of carotid artery plaque, using tooth loss as an indicator of past periodontal disease (115). The results offered first evidence for a contribution of periodontal pathogens during early atherogenesis, which strengthens the connection between periodontitis and vascular events towards a causal one.

\section{Discussion}

The focus of the relationship between cardiovascular disease and periodontal disease is shifting from a purely epidemiological association towards biologic understanding of the underlying mechanism. Current evidence provided by cross-sectional and longitudinal studies has been inconclusive. Conspicuously, several important risk factors are known to contribute to both conditions mutually (Table 1). Although adjustment for known risk factors is routinely considered in epidemiological studies, residual confounding might has to be anticipated (27).

To address the issue of causality, studies based upon plausible biologic concepts between atherogenesis and periodontal diseases are needed, using in vitro cell cultures, animal models, and controlled intervention studies based on molecular markers. Within the limitations of in vitro study models in the basic sciences, the biologic plausibility for a causal relationship seems to be coherent. Direct and indirect biologic connections between periodontitis and atherosclerosis have been demonstrated at different stages of atherogenesis (Table 2). Positive findings of periodontal pathogens in circulation and cardiovascular atheromas are a necessary requirement for local invasion of endothelial cells and for inoculation of pre-existing atherosclerotic plaques. It is possible that $P$. gingivalis affects the vessel wall directly and/or indirectly via inflammatory response, immune responses, and hemostasis. The inflammatory host response does not have to be exclusively triggered by $P$. gingivalis. A current hypothesis suggests an additive or synergistic effect resulting from coincidental bystanders of different origins. Together as total pathogenic burden they might overcome a certain threshold resulting in unequivocal clinical significance.

The connection between various chronic infection and markers of early atherogenesis was prospectively investigated over 5 years in a large population (116). The adjusted odds ratio of 2.78 expressed the chances for participants with a chronic infection to develop atherosclerosis. A total of $36.8 \%$ of individuals suffered from chronic infections, and periodontitis was present in $2.3 \%$ of patients. It was concluded that approximately $40 \%$ of the newly developed atheromas were attributable to chronic infection. Further, bacterial endotoxins and the autoantibody Hsp60 were elevated. Bacterial load was found to correlate with the extent of atherosclerosis and even cardiovascular death, which was even stronger in patients with a high CRP level, possibly representing more inflammation (117-119). The lack of association between endodontically treated teeth and periapical pathology, generally involving only a few teeth, and cardiovascular disease cross-sectional study might support this concept (120).

Infections may potentiate the action of traditional risk factors. Nevertheless, there is no direct evidence that these organisms cause atherosclerotic lesions according to Koch's postulates. Animal models have been used to study the pathogenesis of multifactorial diseases in an attempt to exclude potentially confounding risk factors except the one of interest. Related to $P$. gingivalis the accumulation of risk factors, such as genetic predisposition, diet and infection, appeared to have an additive effect on the lesions (54).

Assuming a true causal link between atherosclerosis and periodontal disease, periodontal treatment is to be expected to reduce the risk of atherosclerosis and cardiovascular disease. All other results have to be interpreted as biases attributed to confounding (121). Intervention approaches aiming 
Table 2. Periodontal infection linked to atherogenesis

\begin{tabular}{|c|c|c|}
\hline Atheroma event & Link to Porphyromonas gingivalis & Source \\
\hline Direct effect & Invasion of endothelial cells & (34) \\
\hline $\begin{array}{l}\text { Initiation of } \\
\text { atherosclerosis }\end{array}$ & Activation of phagocytic cells & $(57,61)$ \\
\hline $\begin{array}{l}\text { Initiation of } \\
\text { atherosclerosis }\end{array}$ & $\begin{array}{l}\text { Elevated serum lipid levels impair } \\
\text { function of PMNs }\end{array}$ & $(123)$ \\
\hline $\begin{array}{l}\text { Initiation of } \\
\text { atherosclerosis }\end{array}$ & Induction of MCP-1 & $(65,66)$ \\
\hline Cytokine induction & $\begin{array}{l}\mathrm{PGE}_{2}, \mathrm{IL}-1 \beta \text {, TNF- } \alpha \text { derived from } \\
\text { periodontitis reach potent systemic levels }\end{array}$ & $(62)$ \\
\hline Increased CRP & $\begin{array}{l}\text { Positive serum samples and carotid } \\
\text { endarterectomy samples }\end{array}$ & $(28,100)$ \\
\hline $\begin{array}{l}\text { Lipid accumulation } \\
\text { (fatty streak) }\end{array}$ & $\begin{array}{l}\text { Lipid deposition in the aorta using a rabbit } \\
\text { model following } P \text {. gingivalis administration }\end{array}$ & $(68)$ \\
\hline $\begin{array}{l}\text { Immune response } \\
\text { Hsp homologues }\end{array}$ & $\begin{array}{l}\text { Cross-reaction in the host tissue through } \\
\text { antibodies produced against bacterial Hsp }\end{array}$ & $(75-77)$ \\
\hline Plaque rupture & Induction of platelet aggregation & $(109,110)$ \\
\hline MMP production & Weakening of atherosclerotic plaque & $(111)$ \\
\hline
\end{tabular}

CRP, C-reactive protein; Hsp, heat shock protein; IL-1 $\beta$, interleukin-1 $\beta$; MCP-1, monocyte attractant protein-1; $\mathrm{PGE}_{2}$, prostaglandin 2 ; PMN, polymorphonuclear leukocyte; TNF- $\alpha$, tumor necrosis factor- $\alpha$.

at the elimination of periodontal pathogens using conventional periodontal therapy include antibiotics or extraction. However, intervention studies on the establishment of a decreased risk in atherosclerosis as a result of periodontal treatment have yet to be published. So far, on an epidemiological basis, edentulous patients have not been shown to have a lower risk for coronary heart disease (122). Whether or not these effects on isolated cells or in animal models are applicable in human subjects with genetic and environmental variations is yet to be determined. Compared to other infectious diseases, the treatment of chronic periodontitis on a long-term basis may prove to be more demanding due to its multifactorial etiology.

\section{Acknowledgements}

This study was supported by the University of Michigan, Periodontal Graduate Student Research Fund.

The authors do not have any financial interests, either directly or indirectly, in the products listed in the study.
8. Meade TW, Mellows S, Brozovic M et al. Haemostatic function and ischemic heart disease: Principle results of the Northwick Park Heart Study. Lancet 1986;2: 533-537.

9. Kannel WB, Wolf PA, Castelli WP, D'Agostino RB. Fibrinogen and risk of cardiovascular disease: The Framingham study. JAMA 1987;258:1183-1186.

10. Ridker PM, Hennekens CH, RoitmanJohnson B, Stampfer MJ, Allen J. Plasma concentration of soluble intercellular adhesion molecule 1 and risks of future myocardial infarction in apparently healthy men. Lancet 1998;351: 88-92.

11. Ridker PM, Cushman M, Stampfer MJ, Tracy RP, Hennekens CH. Plasma concentration of $\mathrm{C}$-reactive protein and risk of developing peripheral vascular disease. Circulation 1998;97:425-428.

12. Ridker PM. Novel risk factors and markers for coronary disease. Adv Intern Med 2000;45:391-418.

13. Xu Q, Willeit J, Marosi $\mathrm{M}$ et al. Association of serum antibodies to heat shock protein 65 with carotid atherosclerosis. Lancet 1993;341:255-259.

14. Xu Q, Kiechl S, Mayr M et al. Association of serum antibodies to heat-shock protein 65 with carotid atherosclerosis: clinical significance determined in a follow-up study. Circulation 1999;100:11691174.

15. Danesh J, Collins R, Appleby P, Peto R. Association of fibrinogen, C-reactive protein, albumin, or leukocyte count with coronary heart disease. Meta-analyses of prospective studies. JAMA 1998;279: 1477-1482.

16. Chiu B. Multiple infections in carotid atherosclerotic plaques. Am Heart $J$ 1999;138:S534-S536.

17. Forng RY, Champagne C, Simpson W, Genco CA. Environmental cues and gene expression in Porphyromonas gingivalis and Actinobacillus actinomycetemcomitans. Oral Dis 2000;6:351-365.

18. Folsom AR, Nieto FJ, Sorlie P, Chambless LE, Graham DY. Helicobacter pylori seropositivity and coronary heart disease incidence. Atherosclerosis risk in communities (ARIC) study investigators. Circulation 1998;98:845-850.

19. Strachan DP, Mendall MA, Carrington $\mathrm{D}$ et al. Relation of Helicobacter pylori infection to 13-year mortality and incident ischemic heart disease in the Caerphilly prospective heart disease study. Circulation 1998;98:1286-1290.

20. Ridker PM, Danesh J, Youngman L et al. A prospective study of Helicobacter pylori seropositivity and the risk for future myocardial infarction among socioeconomically similar U.S. men. Ann Intern Med 2001;135:184-188. 
21. Wald NJ, Law MR, Morris JK, Bagnall AM. Helicobacter pylori infection and mortality from ischaemic heart disease: negative result from a large, prospective study. BMJ 1997;315:1199-1201.

22. Blasi F, Ranzi ML, Erba $M$ et al. No evidence for the presence of Helicobacter pylori in atherosclerotic plaques in abdominal aortic aneurysm specimens. Atherosclerosis 1996;126:339-340.

23. Danesh J, Collins R, Peto R. Chronic infections and coronary heart disease: is there a link? Lancet 1997;350:430-436.

24. Mattila KJ, Nieminen MS, Valtonen V et al. Association between dental health and acute myocardial infarction. $B M J$ 1989;298:779-782.

25. Genco R, Chadda S, Grossi S et al. Periodontal disease is a predictor of cardiovascular disease in native Americans. J Dent Res 1997;76:408.

26. Hujoel PP, Drangsholt M, Spiekerman C, DeRouen TA. Pre-existing cardiovascular disease and periodontitis: a followup study. J Dent Res 2002;81:186-191.

27. Janket S-J, Baird AE, Chuang S-K, Jones JA. Meta-analysis of periodontal disease and risk of coronary heart disease and stroke. Oral Surg Oral Med Oral Pathol Oral Radiol Endod 2003;95:559-569.

28. Grossi SG, Zambon JJ, Ho AW et al. Assessment of risk for periodontal disease. I. Risk indicators for attachment loss. J Periodontol 1994;65:260-267.

29. Dzink JL, Socransky SS, Haffajee AD. The predominant cultiviable microbiota of active and inactive lesions of destructive periodontal diseases. J Clin Periodontol 1988;15:316-323.

30. Loesche WJ, Syed SA, Schmidt E, Morrison EC. Bacterial profiles of subgingival plaques in periodontitis. $J$ Periodontol 1985;56:447-456.

31. Duncan MJ, Nakao S, Skobe Z, Xie H. Interactions of Porphyromonas gingivalis with epithelial cells. Infect Immun 1993;61:2260-2265.

32. Lamont RJ, Oda D, Persson RE, Persson GR. Interaction of Porphyromonas gingivalis with gingival epithelial cells maintained in culture. Oral Microbiol Immunol 1992;7:364-367.

33. Saglie FR, Marfany A, Camargo P. Intragingival occurrence of Actinobacillus actinomycetemconitans and Bacteroides gingivalis in active destructive periodontal lesions. J Periodontol 1988; 59:259-265.

34. Deshpande RG, Khan MB, Genco CA. Invasion of aortic and heart endothelial cells by Porphyromonas gingivalis. Infect Immun 1998;66:5337-5343.

35. Khlgatian $\mathbf{M}$, Nassar $\mathrm{H}$, Chou $\mathrm{H}-\mathrm{H}$, Gibson FC, Genco CA. Fimbriadependent activation of cell adhesion molecule expression in Porphyromonas gingivalis-infected endothelial cells. Infect Immun 2002;70:257-267.

36. Lopatin DE, Blackburn E. Avidity and titer of immunoglobulin $\mathrm{G}$ subclasses to Porphyromonas gingivalis in adult periodontitis patients. Oral Microbiol Immunol 1992;7:332-337.

37. Mahanonda R, Seymour GJ, Powell LW, Good MF, Halliday JW. Effect of initial treatment of chronic inflammatory periodontal disease on the frequency of peripheral blood T-lymphocytes specific to periodontopathic bacteria. Oral Microbiol Immunol 1991;6:221-227.

38. Miller WD. The human mouth as a focus of infection. Dental Cosmos 1891;33:689713.

39. Hunter W. Oral sepsis as a cause of disease. $\mathrm{Br}$ Med J 1900;1:215-216.

40. Silver JG, Martin AW, McBride BC. Experimental transient bacteremias in human subjects with varying degrees of plaque accumulation and gingival inflammation. $J$ Clin Periodontol 1977;4:92-99.

41. Heimdahl A, Hall G, Hedberg M et al. Detection and quantification by lysisfiltration of bacteremia after different oral surgical procedures. J Clin Microbiol 1990;28:2205-2209.

42. Daly CG, Mitchell DH, Highfield JE, Grossberg DE, Stewart DL. Bacteremia due to periodontal probing: a clinical and microbiological investigation. J Periodontol 2001;72:210-214.

43. Geerts SO, Nys M, De MP et al. Systemic release of endotoxins induced by gentle mastication: association with periodontitis severity. $J$ Periodontol 2002;73:73-78.

44. Haraszthy VI, Zambon JJ, Trevisan M, Zeid M, Genco RJ. Identification of periodontal pathogens in atheromatous plaques. $J$ Periodontol 2000;71:1554 1560.

45. Libby P, Egan D, Skarlattos S. Roles of infectious agents in atherosclerosis and restenosis: an assessment of the evidence and need for future research. Circulation 1997;96:4095-4103.

46. Hirose K, Isogai E, Ueda I. Porphyromonas gingivalis fimbriae induce adhesion of monocytic cell line U937 to endothelial cells. Microbiol Immunol 2000;44:17-22.

47. Dorn BR, Dunn WAJ, Progulske-Fox A. Invasion of human coronary artery cells by periodontal pathogens. Infect Immun 1999;67:5792-5798.

48. Bhagat K, Moss R, Collier J, Vallence P. Endothelial 'stunning' following a brief exposure to endotoxin: a mechanism to link infection and infarction? Cardiovasc Res 1996;32:822-829.

49. Amar S, Gokce N, Morgan S, Loukedeli M, Van Dyke TE, Vita JA. Periodontal disease is associated with brachial artery endothelial dysfunction and systemic inflammation. Arterioscler Thromb Vasc Biol 2003;23:1245-1249.

50. Breslow JL. Mouse models of atherosclerosis. Science 1996;272:685-688.

51. Zhang SH, Reddick RL, Piedrahita JA, Maeda N. Spontaneous hypercholesterolemia and arterial lesions in mice lacking apolipoprotein E. Science 1992;258:468-471.

52. Plump AS, Smith JD, Hayek T et al. Severe hypercholesterolemia and atherosclerosis in apolipoprotein E-deficient mice created by homologous recombination in ES cells. Cell 1992;71:343-353.

53. Zhang SH, Reddick RL, Burkey B, Maeda N. Diet-induced atherosclerosis in mice heterozygous and homozygous for apolipoprotein E gene disruption. J Clin Invest 1994;94:937-945.

54. Li L, Messas E, Batista EL, Levine RA, Amar S. Porphyromonas gingivalis infection accelerates the progression of atherosclerosis in a heterozygous apolipoprotein E-deficient murine model. Circulation 2002;105:861-867.

55. Lalla E, Lamster IB, Hofmann MA et al. Oral infection with a periodontal pathogen accelerates early atherosclerosis in apolipoprotein E-null mice. Arterioscler Thromb Vasc Biol 2003;23:1405-1411.

56. Ross R. Atherosclerosis - an inflammatory disease. N Engl J Med 1999;340:115126.

57. De Nardin E. The role of inflammatory and immunological mediators in periodontitis and cardiovascular disease. Ann Periodontol 2001;6:30-40.

58. Glass CK, Witzum JL. Atherosclerosis: the road ahead. Cell 2001;104:503-516.

59. Ross R. The pathogenesis of atherosclerosis: a perspective for the 1990s. Nature 1993;362:801-809.

60. Funk JL, Feingold KR, Moser AH, Grunfeld C. Lipopolysaccharide stimulation of RAW 264.7 macrophages induce lipid accumulation and foam cell formation. Atherosclerosis 1993;98:6782.

61. Shapira L, Warbington M, Van Dyke TE. TNF alpha and IL-1 beta in serum of LJP patients with normal and defective neutrophil chemotaxis. J Periodont Res 1994;29:371-373.

62. Beck J, Garcia R, Heiss G, Voskonas PS, Offenbacher S. Periodontal disease and cardiovascular disease. $J$ Periodontol 1996;67:1123-1137.

63. Gosling J, Slaymaker S, Gu L et al. MCP-1 deficiency reduces susceptibility to atherosclerosis in mice that overexpress human apolipoprotein B. J Clin Invest 1999;103:773-778.

64. Kang I-C, Kuramitsu HK. Induction of monocyte chemoattractant protein-1 by 
Porphyromonas gingivalis in human endothelial cells. FEMS Immunol Med Microbiol 2002;34:311-317.

65. Qi M, Miyakawa H, Kuramitsu HK. Porphyromonas gingivalis induces murine macrophage foam cell formation. Microb Pathog 2003;35:259-267.

66. Kuramitsu HK, Kang IC, Qi M. Interactions of Porphyromonas gingivalis with host cells: implications for cardiovascular disease. J Periodontol 2003;74:85-89.

67. Offenbacher S, Madianos PN, Champagne $\mathrm{C}$ et al. Periodontitis-atherosclerosis syndrome: an expanded model of pathogenesis. J Periodont Res 1999;34: 346-352.

68. Jain A, Batista EL, Serhan C, Stahl GL, Van Dyke TE. Role for periodontitis in the progression of lipid deposition in an animal model. Infect Immun 2003;71: 6012-6018.

69. $\mathrm{Xu} \mathrm{Q}$, Kleindienst $\mathrm{R}$, Schett $\mathrm{G}$ et al. Regression of arteriosclerotic lesions induced by immunization with heat shock protein 65-containing material in normocholesterolemic, but not hypercholesterolemic rabbits. Atherosclerosis 1996;123:145-155.

70. Wick G, Kleindienst $\mathrm{R}$, Schett $\mathrm{G}$, Amberger A, Xu Q. Role of heat shock protein $65 / 60$ in the pathogenesis of atherosclerosis. Int Arch Allergy Immunol 1995;107:130-131.

71. Maeda H, Miyamoto $\mathrm{M}$, Hongyo $\mathrm{H}$, Nagai A, Kurihara H, Muryama Y. Heat shock protein 60 (GroEL) from Porphyromonas gingivalis: molecular cloning and sequence analysis of its gene and purification of the recombinant protein. FEMS Microbiol Lett 1994;124:121-122.

72. Lopatin DE, Shelburne CE, Van Poperin N, Kowalski CJ, Bagramian RA. Humoral immunity to stress proteins and periodontal disease. $J$ Periodontol 1999;70:1185-1193.

73. $\mathrm{Xu} \mathrm{Q}$, Dietrich $\mathrm{H}$, Steiner $\mathrm{HJ}$ et al. Induction of artherosclerosis in normocholesterolemic rabbits by immunization with heat-shock protein 65 . Arterioscler Thromb 1992;12:789-799.

74. Mori Y, Kitamura H, Song QH, Kobayashi T, Uemura S, Oyong JC. A new murine model for atherosclerosis with inflammation in the periodontal tissue induced by immunization with heat shock protein. Hypertens Res 2000;23:475-481.

75. Choi J, Chung S-W, Kim S-J, Kim S-J. Establishment of Porphyromonas gingivalis-specific $\mathrm{T}$ cell lines from atherosclerosis patients. Oral Microbiol Immunol 2001;16:316-318.

76. Choi J-I, Chung S-W, Kang H-S, Rhim BY, Kim S-J, Kim S-J. Establishment of Porphyromonas gingivalis heat-shock- protein-specific T-cell lines from atherosclerosis patients. J Dent Res 2002;81: 344-348.

77. Chung S-W, Kang H-S, Park H-R, Kim S-J, Kim S-J, Choi J-I. Immune responses to heat shock protein in Porphyromonas gingivalis infected periodontitis and atherosclerosis patients. J Periodont Res 2003;38:388-393.

78. Ridker PM, Cushman M, Stampfer MJ Tracy RP, Hennekens CH. Inflammation, aspirin, and the risk of cardiovascular disease in apparently healthy men. $N$ Engl $J$ Med 1997;336:973979.

79. Koenig W, Sund M, Frohlich M et al C-reactive protein, a marker of inflammation, predicts future risk of coronary heart disease in initially healthy middleaged men: results from the MONICA (Monitoring Trend and Determinants in Cardiovascular Disease) Augsburg cohort study, 1984-92. Circulation 1999;99: 237-242.

80. Kuller LH, Tracy RP, Shaten J, Meilahn EN. Relation of C-reactive protein and coronary heart disease in the MRFIT nested case-control study. Multiple risk factor intervention trial. Am J Epidemiol 1996;144:537-547.

81. Ridker PM, Hennekens CH, Buring JE, Rifai N. C-reactive protein and other markers of inflammation in the prediction of cardiovascular disease in women. $N$ Engl J Med 2000;342:836-843.

82. Zhang YX, Cliff WJ, Schoefl GI, Higgins G. Coronary C-reactive protein distribution: its relation to development of atherosclerosis. Atherosclerosis 1999;145: 375.

83. Pepys MB, Rowe IF, Baltz ML. C-reactive protein: binding to lipids and lipoproteins. Int Rev Exp Pathol 1985;27: 83-111.

84. Folsom AR, Pankow JS, Tracy RP et al The investigator of the NHBLI family heart study. Association of C-reactive protein with markers of prevalent atherosclerotic disease. Am $J$ Cardiol 2001;15:112-117.

85. Zwaka TP, Hombach V, Torzewski J. C-reactive protein-mediated low density lipoprotein uptake by macrophages: implications for atherosclerosis. Circulation 2001;103:1194-1197.

86. Seifert PS, Hugo F, Hansson GK Bhakdi S. Prelesional complement activation in experimental atherosclerosis. Terminal C5b-9 complement deposition coincides with cholesterol accumulation in the aortic intima of hypercholesterolemic rabbits. Lab Invest 1989;60:747754.

87. Lagrand WK, Niessen HWM, Wolbink G-J et al. C-reactive protein colocalizes with complement in human hearts during myocardial infarction. Circulation 1997;95:97-103.

88. Torzewski J, Torzewski M, Bowyer DE et al. C-reactive protein frequently colocalizes with the terminal complement complex in the intima of early atherosclerotic lesions of human coronary arteries. Arterioscler Thromb Vasc Biol 1998;18:1386-1392.

89. Reynolds GD, Vance RP. C-reactive protein immunohistochemical localization in normal and atherosclerotic human aortas. Arch Pathol Lab Med 1987;111:265-269.

90. Yudkin JS, Stehouwer CD, Emeis JJ, Coppack SW. C-reactive protein in healthy subjects: association with obesity, insulin resistance, and endothelial dysfunction: a potential role for cytokines originating from adipose tissue? Arterioscler Thromb Vasc Biol 1999;19:972978.

91. Fichtlscherer S, Rosenberger G, Walter DH, Breuer S, Dimmler S, Zeiher AM. Elevated C-reactive protein levels and impaired endothelial vasoreactive patients with coronary artery disease. Circulation 2000;102:1000-1006.

92. Sitzer M, Markus HS, Mendall MA, Liehr R, Knorr U, Steinmetz H $\mathrm{C}$-reactive protein and carotid intimal medial thickness in a community population. J Cardiovasc Risk 2002;9:97-103.

93. Danesh J, Wheeler JG, Hirschfield GM et al. C-reactive protein and other circulating markers of inflammation in the prediction of coronary heart disease. N Engl J Med 2004;350:1387-1397.

94. Ebersole JL, Machen RL, Steffen ML, Willmann DE. Systemic acute-phase reactants, C-reactive protein and haptoglobin, in adult periodontitis. Clin Exp Immunol 1997;107:347-352.

95. Fredriksson MI, Figueredo CMS, Gustafsson A, Bergström KG, Asman BE. Effect of periodontitis and smoking on blood leukocytes and acute-phase proteins. J Periodontol 1999;70:13551360.

96. Loos BG, Craandijk J, Hoek FJ, Wertheim-van-Dillen PM, van der Velden U. Elevation of systemic markers related to cardiovascular diseases in the peripheral blood of periodontitis patients. J Periodontol 2000;71:1528-1534.

97. Wu T, Trevisan M, Genco RJ, Falkner KL, Dorn JP, Sempos CT. Examination of the relation between periodontal health status and cardiovascular risk factors: serum total high density lipoprotein cholesterol, C-reactive protein and plasma fibrinogen. Am J Epidemidol 2000;151:273-282.

98. Slade GD, Offenbacher S, Beck JD Heiss G, Pankow JS. Acute-phase inflammatory response to periodontal 
disease in the US population. $J$ Dent Res 2000;79:49-57.

99. Noack B, Genco RJ, Trevisan M, Grossi S, Zambon JJ, De Nardin E. Periodontal infections contribute to elevated systemic C-reactive protein level. J Periodontol 2001;72:1221-1227.

100. Glurich I, Grossi S, Albini B et al. Systemic inflammation in cardiovascular and periodontal disease: Comparative study. Clin Diagn Lab Immunol 2002;9: 425-432.

101. Ghezzi E, Ship JA. Systemic diseases and their treatments in the elderly: impact on oral health. $J$ Public Health Dent 2000;60:289-296.

102. Joshipura K, Pitiphat W, Douglass CW. Validation of self-reported periodontal measures among health professionals. $J$ Public Health Dent 2002;62:115-121.

103. Wakai K, Kawamura T, Umemura O et al. Association of medical status and physical with periodontal disease. J Clin Periodontol 1999;26:664-672.

104. Craig RG, Yip JK, So MK, Boylan RJ, Socranscy SS, Haffajee AD. Relationship of destructive periodontal disease to the acute-phase response. $J$ Periodontol 2003;74:1007-1016.

105. Mattila K, Vesanen M, Valtonen V et al. Effect of treating periodontitis on C-reactive protein levels: a pilot study. BMC Infect Dis 2002;2:30-33.

106. McGill HCJ. Fatty streaks in the aorta and coronary arteries and aorta. Lab Invest 1968;18:560-564.

107. Lowe GDO. Etiopathogenesis of cardiovascular disease: hemostasis, thrombosis, and vascular medicine. Ann Periodontol 1998;3:121-126.

108. Herzberg MC, Brintzenhofe KL, Clawson CC. Aggregation of human platelets and adhesion of Streptococcus sanguis. Infect Immun 1983;39:1457-1469.

109. Herzberg MC, Meyer MW. Effects of oral flora on platelets: Possible consequences in cardiovascular disease. $J$ Periodontol 1996;67:1138-1142.

110. Sharma A, Novak EK, Sojar HT, Swank RT, Kuramitsu HK, Genco RJ. Porphyromonas gingivalis platelet aggregation activity: outer membrane vesicles are potent activators of murine platelets. Oral Microbiol Immunol 2000;15:393396.

111. Kuramitsu HK, Qi M, Kang I-C, Chen W. Role for bacteria in cardiovascular disease. Ann Periodontol 2001;6:41-47.

112. O'Leary DH, Polak JF, Kronmal RA, Manolio TA, Burke GL, Wolfson SKJ. Carotid-artery intima and media thickness as a risk factor for myocardial infarction and stroke in older adults. Cardiovascular Health Study Collaborative Research Group. $N$ Engl J Med 1999;340:14-22.

113. Chambless LE, Heiss G, Folsom AR et al. Association of coronary heart disease incidence with carotid arterial wall thickness and major risk factors: the Atherosclerosis Risk in Communities (ARIC) Study, 1987-93. Am J Epidemiol 1997;146:483-494.

114. Beck JD, Elter JR, Heiss G, Couper D, Mauriello SM, Offenbacher S. Relationship of periodontal disease to carotid artery intima-media wall thickness. The Atherosclerosis Risk in Communities (ARIC) Study. Arterioscler Thromb Vasc Biol 2001;21:1816-1822.

115. Desvarieux M, Demmer RT, Rundek T et al. Relationship between periodontal disease, tooth loss, and carotid artery plaque. The oral infections and vascular disease epidemiology study (INVEST). Stroke 2003;34:2120-2125.

116. Kiechl S, Egger G, Mayr $M$ et al. Chronic infections and the risk of carotid atherosclerosis: prospective results from a large population study. Circulation 2001;103:1064-1070.

117. Espinola-Klein C, Rupprecht HJ, Blankenberg $\mathrm{S}$ et al. Impact of infectious burden on extend and long-term prognosis of atherosclerosis. Circulation 2002;105:15-21.

118. Zhu J, Quyyumi AA, Norman JE et al. Effects of total pathogen burden on coronary artery disease risk and c-reactive protein level. Am J Cardiol 2000;85:140146.

119. Epstein SE, Zhu J, Burnett MS, Zhou YF, Vercellotti G, Hajjar D. Infection and atherosclerosis: potential roles of pathogen burden and molecular mimicry. Arterioscler Thromb Vasc Biol 2000;20: 1417-1420.

120. Frisk $F$, Hakeberg $M$, Ahlqwist $M$, Bengtsson C. Endodontic variables and coronary heart disease. Acta Odontol Scand 2003;61:257-262.

121. Joshipura KJ, Douglass $\mathrm{CW}$, Willett WC. Possible explanations for the tooth loss and cardiovascular disease relationship. Ann Periodontol 1998;3: 175-183.

122. Hujoel PP, Drangsholt M, Spiekerman C, DeRouen TA. Examining the link between coronary heart disease and the elimination of chronic dental infections. J Am Dent Assoc 2001;132:883889.

123. Cutler CW, Iacopino AM. Periodontal disease: links with serum lipid/ triglyceride levels? Review and new data. J Int Acad Periodontol 2003;5:47-51. 